\title{
Transition Programs for Student Veterans
}

\author{
Gary Ritz, Alyssa Heggen, Katie Ericson, and Jacqueline Harris
}

Many times, student veterans are returning to, or entering for the first time, an institution of higher education at an older age than the traditional student, and with very different background experiences. As institutions prepare a welcoming environment for their matriculating students, an orientation program for student veterans, supplemental to the already existing orientation, is suggested. Doing so provides all the necessary information to the student veteran about the institution, along with a separate time to create a support group with his or her peers. The program described was implemented at a four-year, public, Midwestern university in the fall semester of 2011. Through a multi-pronged approach, student veterans were offered a variety of resources to help ease the transition from "boots to books." An analysis of the data on the students who participated in the activities was compared to data on the students who were not involved. The results of the analysis show positive support for continuing the specialized orientation program.

\section{Review of Literature}

The Department of Veteran Affairs estimates that more than two million veterans of the War on Terror are eligible to pursue postsecondary education after the passing of the Veteran's Education Assistance Act, also known as the Post 9/11 GI Bill, in 2008 (Vance \& Miller, 2009). In a survey sent to 380 student veterans, nearly 75 percent cited the educational benefits from the Post 9/11 GI Bill as the main source of their education funding (Lokken, Pfeffer, McAuley, \& Strong, 2009); however, it is predicted that many may not enroll in postsecondary education due to lack of information and ineffective marketing to veterans (Vance \& Miller, 2009).

\section{Veterans and Transition}

Students of color, first-generation students, and low-income students are typically considered historically underserved students in higher education, but

Gary Ritz (garitz@bsu.edu) is the Learning Center Director and Mathematics and Business Tutoring Coordinator at Ball State University.

Alyssa Heggen (Alyssa.heggen@gmail.com) is a School Counselor (Former Veterans Affairs Graduate Assistant) at Fort Wayne Homestead High School.

Katie Ericson (Katie.ericson@ttu.edu) is the Resident Life Coordinator at Texas Tech University.

Jacqueline Harris (harri407@purdue.edu) works with Postsecondary Outreach at the Military Family Research Institute at Purdue University. 
many educators are also placing student veterans in this category (Branker, 2009). According to Green (2006), historically underserved students are generally not served well in postsecondary institutions. These students find transitioning to college, as well as adjusting to social and academic responsibilities and demands, to be a dramatic change. While living in the military culture, troops experience a profound sense of purpose, commitment to a critically important mission, deep camaraderie, and the intense stimulation of the battlefield (Church, 2009); thus, the relative calmness of the classroom, along with classmates who often possess worldviews not shaped by the types of experiences acquired during military service, can feel mundane or unreal.

In a number of states, there are programs to assist veterans returning to civilian life, such as Minnesota's Beyond the Yellow Ribbon project (Lokken et al., 2009). However, Cantrell and Dean (2007) observed that, many times, potential students are not fully educated on resources available to them, both on and off campus, and many student veterans may not enroll in higher education because of an absence of effective outreach, easily accessible information, and other veteran-friendly practices.

On many campuses, depending on the student veteran population, a successful transition will depend almost entirely on the individual veteran's success in establishing goals, finding mentors, and developing confidantes (Vance et al., 2010). Veterans may find this difficult, as they are accustomed to following the commands of an officer or point person who provides guidance. Ideally, veterans should have resources, personnel, and on-going programs which offer engagement (Branker, 2009). In fact, a priority reported by student veterans was to have a designated point person on campus for veterans to contact (Vance \& Miller, 2009).

\section{Assisting Veterans}

While serving our country, military service members had to make adaptations to survive under threat; they shouldn't have to deal with uncertainty and stress while at college due to poor design of programs (Branker, 2009). Creating an environment in which veterans, military members, and their families feel welcome is crucial for postsecondary education institutions (Lokken et al., 2009). Notably, among veteran-friendly campuses, collaboration between student affairs and academic affairs departments has been established and shows promise (Burnett \& Segoria, 2009).

Another beneficial resource that should be available for veterans is a student organization that provides students the opportunity to meet other student veterans, engage in activities, and discuss issues that others may be facing. A national resource is Student Veterans of America (2011), which is a coalition of student veteran groups from higher education campuses across the nation. This group involvement allows veterans to find a place with others who have similar experiences, participate in activities, learn more about resources available on campus, and become involved in other organizations (Burnett \& Segoria, 2009). Building a networking support system can be one of the most helpful resources on 
a college campus for student veterans (Vance et al., 2010).

Keeping busy and having a set daily schedule is also beneficial to assist student veterans in the transition process (Runmann \& Hamrick, 2010). Many veterans are accustomed to very specific schedules, and with the help of academic advisors and other key staff, keeping classes, work, and extracurricular activities organized can be accomplished. Other suggestions to create a community and assist student veterans in the transition to higher education include assigning academic credit for military service, establishing programs for suicide prevention, providing programs for family and marriage counseling, dedicating space to be used as a resource area for veterans, and forming intramural sports teams (Vance et al., 2010). Another option for assisting students is an orientation program.

\section{Orientation Programs}

Orientation programs are used at almost every higher education institution as a successful tool for students to complete a smooth introduction and transition to the collegiate experience (Upcraft \& Farnsworth, 1984). Goals commonly include academic preparation, personal adjustment, extracurricular activities, campus orientation, and an increased awareness of university life for students and parents (Hollins, 2009).

One example of an orientation program for a targeted population is the Student Orientation Advising Registration (SOAR) program in Virginia. Students who participated in orientation were retained at a higher rate of $77.6 \%$, compared to those who did not participate, at $57.9 \%$ (Hollins, 2009). However, this program is designed to assist transfer students and is not specifically tailored to student veterans; in fact, there is a dearth of publications detailing specific orientation programs for student veterans.

\section{History of Outreach to Veterans}

Three years ago, Ball State University (BSU) was awarded start-up money from the Lilly Endowment to provide and coordinate campus services for student veterans through a grant administered by the Military Families Research Institute at Purdue University. During this time, various programs and services were devised for student veterans. For two years, there was an open house in the Learning Center for student veterans and their families at the onset of the academic year. Each semester, at least one meeting was offered to student veterans on topics such as study skills, midterm preparation, and veterans' benefits. Speakers from the Learning Center, Counseling Center, Veterans Affairs office, Veterans Affairs Clinic, and Disabled Student Development met with student veterans and offered information. Additionally, the Student Veterans Organization and Salute Honor Society were established on campus. Significant steps were taken to develop a transitions class just for student veterans with a focus on study skills. However, the designers of this course realized that much of this information needed to be 
offered to students prior to the start of an academic year. This led the authors of the current article to construct the following transition program for student veterans.

\section{Program Objectives}

A supplemental transition program directed specifically for student veterans was created to provide a support system and community for veterans either entering higher education for the first time or returning after deployments and service-related duties. The objectives of the program were 1) building community among the student veterans, 2) easing the transition into a postsecondary institution, 3) understanding campus and community resources provided to student veterans, and 4) interpreting and understanding veteran benefits.

\section{Method and Design}

The following model for a student veteran transition program was designed in response to the unique needs of the student veteran population on campus. Ball State University created a transition program containing three main parts: Online Transition to College Modules, Welcome Week Orientation Day, and the Online Student Veteran Resource Center.

\section{Part One - Transition to College Modules}

The first part of the orientation program consisted of four online modules that were placed on the website of the BSU Veterans' Affairs office. The information posted on the site served as pre-college online orientation modules and contained the information that is most pertinent for student veterans to know prior to attending college. The Veterans' Affairs office notified "New to BSU" student veterans of these modules and website during the summer. A gift card incentive was provided to motivate these students to complete the precollege online modules prior to attending Part Two (Welcome Week Orientation Day) of the transition program. These modules were not required but highly recommended for the student veterans to complete (see the website for specifics about each module: http://cms.bsu.edu/admissions/scholarshipsandfinancialaid/ typesofaid/veteransanddependentseducationalbenefits/orientationprogram/ transitiontocollege).

Module one: Office of Veterans' Affairs and Veterans Benefits. This module helped the student veterans become familiar with the individuals they will be working closely with throughout their higher education experience. It included an introduction to the institution by the leader of the Veterans' Affairs office on campus and familiarized the veterans with the forms they must complete and benefits they can receive from legislation and federal aid such as the Post 9/11 G.I. Bill, FAFSA, and Pell 
grants (see http://cms.bsu.edu/admissions/scholarshipsandfinancialaid/ typesofaid/veteransanddependentseducationalbenefits/orientationprogram/ transitiontocollege/officeofveteranaffairsandveteransbenefits).

Module two: College terminology. This module included common terms that students may need to know prior to attending classes to help in the transition to campus life and academic coursework (see http:// cms.bsu.edu/admissions/scholarshipsandfinancialaid/typesofaid/ veteransanddependentseducationalbenefits/orientationprogram/ transitiontocollege/collegeterminology).

Module three: Moving to Muncie, Indiana and Ball State. This module contained information and advice for moving to the specific city and area of the institution; for Ball State University, the city is Muncie, Indiana (see http://cms.bsu.edu/admissions/scholarshipsandfinancialaid/typesofaid/ veteransanddependentseducationalbenefits/orientationprogram/ transitiontocollege/moving).

Module four: Getting off to a good start academically. This module helped students become prepared for courses prior to attending class and was intended to assist in the transition from military life to civilian life. Information was provided to help student veterans become familiar with using a syllabus, contacting and communicating with professors, and managing time effectively (see http://cms.bsu.edu/admissions/scholarshipsandfinancialaid/typesofaid/ veteransanddepenentseducationalbenefits/orientationprogram/transitiontocollege/ gettingofftoagoodstartacademically).

\section{Part Two - Welcome Week Orientation Day}

The purpose of this orientation day was to build community among the incoming student veterans and familiarize them with resources that are available on campus. The goal was to give student veterans who attended orientation a feeling of comfort about their new environment and support by other student veterans and key faculty members. The orientation day was hosted by a team of university faculty members from the Learning Center and Veterans Affairs office who work very closely with student veterans. Orientation leaders consisted of current student veterans who were active members in the university's Student Veteran's Organization (SVO). The purpose of having student veterans as orientation leaders was to help facilitate a mentorship while the new student veterans transitioned into academia.

The orientation day began with a number of icebreaker activities to fulfill the objective of allowing students to get to know one another and organize them into small working groups. Each small group was then assigned an orientation leader who worked with them for the remainder of the day. Once the small groups were formed, each group did a "commonalities and uniqueness" exercise to further build relationships with their peers.

The next objective was to familiarize the students with key locations and landmarks on the university campus. This objective was accomplished through 
a campus-wide scavenger hunt that was led by the orientation leaders. The orientation leaders were key contributors to this activity as they showed new student veterans the best way to navigate campus.

After the scavenger hunt, a presentation was given to educate student veterans about what to expect during their first semester and to show them the online resource center. This was an opportunity for student veterans to ask any questions they may have about beginning classes. The orientation leaders were also able to discuss the university's Student Veteran Organization (SVO) and benefits of being a member.

After the presentation, student veterans participated in a "Roadblocks" activity. Student veterans were instructed to anonymously write a "roadblock" or challenge/ fear/worry they expect to have in the upcoming semester. Orientation leaders played an active role during this activity in facilitating group discussion and building cohesion among the group. This exercise provided a means for student veterans to better understand the unique qualities that come with being a student veteran.

The orientation day ended with a tour of Muncie. Student veterans were provided with a bus, which transported them around town while stopping at key locations, such as the local VA clinic, informing students of their hours and services. The purpose of the tour was to familiarize student veterans with the university town. The end of the tour concluded the orientation day.

\section{Part Three: Online Student Veteran Resource Center}

The Student Veteran Resource Center supplied resource information to student veterans and their families prior to arriving on campus. Because there was often a need for families to learn about college terms and procedures, information about offices and services was now available in a 24/7 online format. The resources remained on the site for reference throughout the school year. Information included various topics such as Disabled Student Development, Parking Service, and the Ombudsperson. Also offered was a list of fifteen links to a wide range of study strategies topics. Valuable information and resources were included for students to reference while attending Ball State (see http://cms.bsu.edu/admissions/scholarshipsandfinancialaid/ typesofaid/veteransanddependentseducationalbenefits/orientationprogram/ ballstatestudentveteranresourcecenter).

\section{Other Outreach Initiatives:}

Once classes started, offerings to veterans continued in a variety of formats. Students were invited to join the Student Veterans Organization. They were sent weekly email newsletters, which kept them current with academic schedules and on-campus events. A Blackboard community was established, and messages were sent through this form of communication. Social events such as a bowling party were held. Academic meetings were held over the lunch hour at least once a semester. Staff in the Learning Center sent messages to students upon referral by 
the Veterans' Affairs officer. They also set aside specific hours each week to meet with student veterans for tutoring and general academic assistance.

\section{Results}

In assessing the academic effectiveness of this supplemental orientation program for the "New to BSU" student veterans' semester Grade Point Average (GPA), retention, and credit hour completion were investigated.

\section{Orientation Participation}

Because the BSU traditional summer orientation program is primarily focused on incoming freshman who just graduated high school, student veterans might not feel comfortable in that orientation environment. Many of these student veterans are older with already established life experiences and might have difficulty relating to the traditional matriculating freshman.

The analysis for student veterans who participated in each of the orientation programs and activities is illustrated in Table 1. Participation in some of the orientation activities and programs was relatively low. Through the BSU Veterans' Affairs transition program, 13 "New to BSU" student veterans $(21.7 \%)$ who did not attend the Ball State traditional orientation program were contacted. The Veterans' Affairs supplemental orientation program allowed those students to have similar orientation experiences in an environment with peers closer to their age and with similar experiences.

Of the 60 "New to BSU" student veterans, 23 of them attended Ball State's traditional summer orientation program. This means that $61.7 \%$ of the incoming student veterans would not have been involved in any college transitional programs prior to attending college, leaving them without appropriate knowledge of the campus and its resources.

\section{Grade Point Averages (GPA)}

In assessing the effectiveness of the Veterans' Affairs orientation program in relation to academic success, the fall 2011 semester GPA of the "New to BSU" student veterans was investigated. The fall 2011 semester GPA was calculated for these 60 students in relation to the orientation activities in which they participated. Table 2 illustrates the semester GPAs of the student veterans who participated in the orientation activity or combination of activities compared to the student veterans who did not participate in the orientation activity or the supplemental veterans' activities. In all but one of the orientation activity category groupings, the average semester GPA of the "New to BSU" student veterans who participated in the Veterans' Affairs orientation activity was higher than the average semester GPA of the student veterans who did not participate. The only orientation category group in which the GPA was not higher is represented by the 23 student veterans 


\section{Student Veteran Participation in Orientation Activities}

Orientation Activity

Number of "New to BSU"

Student Veterans

Participating in the Activity
Percentage of Participating

"New to BSU"

Student Veterans $(n=60)$

Ball State Traditional

Summer Orientation

Any Ball State Veterans Affairs

Supplemental Orientation Activity *

Orientation Modules

Both BSU Veterans Affairs

Pre-College Orientation Modules

Both BSU Traditional Summer

Orientation Activity *

* Any Orientation Activity would be participating in the Veterans Affairs Orientation Day or completing the Online Pre-College Orientation Modules.

who participated in the BSU traditional orientation program (2.795), compared to the 37 student veterans who did not participate in the traditional program (2.876). The highest semester GPA was found for the group of 10 "New to BSU" student veterans who completed both the Online Pre-College Orientation Modules and attended the Veterans' Affairs Orientation Day. The average semester GPA for these 10 student veterans was 3.527, compared to 2.795 for the remaining 50 student veterans who did not complete this combination of orientation activities.

In trying to compare the semester GPA of these 60 "New to BSU" student veterans to a cohort group out of the general student population at Ball State, the authors were only able to obtain fall 2011 semester GPA information for all Ball State freshmen, which is defined as any student who has earned less than 30 credit 


\section{"New to BSU" Student Veteran Semester GPA Comparisons based on Orientation Activities (Fall Semester 2011)}

Orientation Activity
Average Semester GPA for Fall 2011 for "New to BSU"

Student Veterans that DID

Participate in the Activity
Average Semester GPA for Fall 2011 for "New to BSU"

Student Veterans that DID NOT Participate in the Activity

Ball State Traditional

2.795

2.876

Summer Orientation

Any Ball State Veterans Affairs

3.264

2.576

Supplemental Orientation Activity*

Ball State Veterans Affairs

Orientation Day

Online Pre-College Orientation

3.070

Modules

Day and Online Pre-College

Orientation Modules

Both BSU Traditional Summer

3.085

2.795

Orientation and Veterans Affairs

Orientation Activity *

Both BSU Traditional Summer

Orientation and Veterans Affairs

Orientation Day

* Any Orientation Activity would be participating in the Veterans Affairs Orientation Day or completing the Online Pre-College Orientation Modules.

hours. Table 3 illustrates the comparison of the average Fall 2011 semester GPA for the "New to BSU" student veterans to the semester GPA for all BSU freshmen and all BSU students. The average semester GPA for the student veterans was higher than the average all freshmen semester GPA, but lower than the all BSU average semester GPA. 


\section{"New to BSU" Student Veteran Semester GPA Comparisons to Ball State Student Body (Fall Semester 201 1)}

\author{
Average Semester GPA \\ for All "New to BSU" \\ Student Veterans for Fall 2011
}

\author{
Average Semester GPA \\ for All Ball State Freshmen \\ for Fall 2011*
}

Average Semester GPA for All Ball State Undergraduate Students for Fall 2011*

$(\mathrm{N}=60)$

$(\mathrm{N}=4871)$

$(\mathrm{N}=16420)$

* Source: Ball State's Office of the Registrar 01/13/12

\section{Retention}

Retention data was based on the fall 2011 "New to BSU" student veterans returning for classes during the spring 2012 semester. Table 4 illustrates the orientation activity groups used in previous tables and shows the retention percentage of the "New to BSU" student veterans who returned for the spring 2012 semester. In all of the orientation activity categories, the retention rate was $80 \%$ or higher, with all but one category being $90 \%$ or higher. Both categories in which $100 \%$ retention was obtained involve participation in the Veterans' Affairs Orientation Day. Of the 60 "New to BSU" student veterans in this study, $90 \%$ returned for the spring 2012 semester, compared to $92.7 \%$ of all BSU matriculating freshman.

\section{Credit Hour Completion}

Because credit hours attempted and completion of these hours often affect the benefits that the student veterans received, investigation was done in these areas for the 60 "New to BSU" students veterans of this study. Table 5 compares the number of credit hours attempted, earned and the percentage of completion of credit hours during the fall 2011 semester for the "New to BSU" student veterans who participated in any Veterans' Affairs orientation activity (23 student veterans) to those student veterans who did not participate (37 student veterans). The "New to BSU" student veterans who did participate in a Veterans' Affairs orientation activity attempted more credit hours, completed more credit hours, and had a higher completion percentage than those student veterans who did not participate in a Veterans' Affairs orientation activity. 


\section{"New to BSU" Student Veteran Retention Information (Retention is Based on the Student Returning for the Spring 2012 Semester)}

Orientation Activity

\author{
Percentage of "New to BSU" Student \\ Veterans Participating in the Activity \\ (in parentheses are the students \\ returning/total students in the category)
}

Ball State Traditional Summer Orientation

Any Ball State Veterans Affairs

Supplemental Orientation Activity *

Ball State Veterans Affairs Orientation Day

Online Pre-College Orientation Modules

Both BSU Veterans Affairs Orientation Day

and Online Pre-College Orientation Modules

Both BSU Traditional Summer Orientation and

a Veterans Affairs Orientation Activity *

Both BSU Traditional Summer Orientation

and Veterans Affairs Orientation Day

All "New to BSU" Student Veterans
$95.7 \%(22 / 23)$

$95.7 \%(22 / 23)$

$100 \%(21 / 21)$

$83.3 \% \quad(5 / 6)$

$100 \% \quad(4 / 4)$

$90 \%(9 / 10)$

$100 \%(8 / 8)$

$90 \%(54 / 60)$

* Any Orientation Activity would be participating in the Veterans Affairs Orientation Day or completing the Online Pre-College Orientation Modules.

\section{Discussion}

By offering this program to student veterans, collecting relevant data, and evaluating their responses, the initial program objectives were met: transition into the university was facilitated through community building and resource awareness. Additionally, the website and orientation day provided platforms to discuss veterans' benefits, thereby removing that particular stress for the students.

A gap in student veteran participation in the traditional orientation program is one that needs to be addressed; only 23 of the 60 student veterans at BSU participated in the traditional program. Providing transitional academic programs 


\section{"New to BSU" Student Veteran Credit Hour Information (Fall Semester 2011)}

Category

\author{
"New to BSU" Student \\ Veterans that participated \\ in a Veterans Affairs \\ Orientation Activity*
}

\author{
"New to BSU" Student \\ Veterans that did not participate \\ in a Veterans Affairs \\ Orientation Activity*
}

Average Number of Credit Hours

ATTEMPTED by the Student Veteran

Average Number of Credit Hours

EARNED by the Student Veteran

Percentage of Completion of the

Attempted Credit Hours by the

Student Veteran
14.39 credits

13.78 credits

13.74 credits

12.56 credits

$95.47 \%$
$86.49 \%$

* Any Orientation Activity would be participating in the Veterans Affairs Orientation Day or completing the Online Pre-College Orientation Modules.

and information about campus resources is needed for all students and reinforces the importance of offering a supplemental orientation program such as the one outlined for student veterans.

When looking specifically at the components of the transition program, Transition to College modules was an appropriate overview for students to read prior to entering college. These modules laid the groundwork for students to gain critical information about the Veterans' Affairs office, academic resources, and the surrounding community. The number of students who accessed this information was tracked throughout the summer, and although the number of students who initially accessed the information was small, publicity has been ongoing throughout the school year. As a result, more students have turned to these modules for valuable information.

The effectiveness of Welcome Week Orientation Day is demonstrated in the retention data. Student veterans who participated in the orientation earned more credit hours, higher GPAs, and were retained from Fall to Spring Semester at $100 \%$. In addition, participants reported learning more about their benefits and resources and other student veterans. An important point to remember with regard to the orientation day is that, although the student veterans were invited to the university's traditional summer orientation program offered to all in-coming freshmen, $61.7 \%$ of the eligible student veterans did not attend it, indicating the likelihood of a significant gap in information about campus resources. Attendance 
at the orientation day for student veterans provided important information for this at-risk group.

The Online Student Veteran Resource Center contained links to information and resources for students to use throughout the school year. In addition to information about offices and campus personnel, study tips are listed by topic on this site; suggestions for time management and test preparation are easily available for students to read. Publicity was sent throughout the academic year to remind students to use this website. Although this study serves to report one school's efforts to meet the needs of student veterans, the initial results are very promising and are offered as ideas to be considered by other institutions.

\section{Limitations and Recommendations}

Institutions of higher education need to thoughtfully design programs to offer veterans a safe, smooth, and supportive transition to educational advancement with the emphasis of future occupational opportunities. The transitional support services should be broader than providing assistance to the wounded warriors (Vance \& Miller, 2009). There is a need to update university programs and services to better serve veterans (Herrmann et al., 2008). Planning should incorporate collaboration across campus with a point person in the Veterans' Affairs office. Staff across campus can effectively collaborate to organize resources. Such a program had positive results at Ball State University in the areas of GPA, retention, and credit hours.

Limitations to consider in this study include sample size, timing of publicity, self-selection, data access, and a lack of long-term analysis. The small sample size of student veterans who participated in the student veteran orientation program has inherent and obvious limitations. In terms of timing, the online information was posted on the website a month before the academic year began, which did not give a great deal of time to publicize the site. In addition, students who did participate in the orientation program were self-selected: the type of student to volunteer their participation in an orientation program may already have the intrinsic motivation to succeed in higher education, thus creating a bias within our sample. Ideally, the authors would have liked to have compared the student veterans to only the fall 2011 matriculating freshmen; that data was not available from the BSU Registrar's Office. Although this is not a longitudinal study, but rather a snapshot of one semester with one group of student veterans, the results are impressive. Future analysis of orientation programs should include data from multiple semesters, rather than the two semesters that were available for this study.

Future orientation programs should include activities and discussions that involve parents and family members. An unanticipated outcome of the orientation day was the number of parents who chose to participate with their child, demonstrating a need for continual communication with parents and family members regarding higher education and veteran benefits. In the future, additional activities will be planned for attending family members. One idea is to offer structured activities that encourage building a community among the parents of 
the student veterans.

We highly recommended that orientation programs designed for specific student populations, such as student veterans, be implemented. This transition program would be supplemental to other standard orientation programs that the university offers.

\section{References}

About SVA. (2011). Student Veterans of America. http://www.studentveterans. org/about/ Branker, C. (2009). Deserving design: The new generation of student veterans. Journal of Postsecondary Education and Disability, 22(1), 59-66. Retrieved from http://www.ahead.org/publications/jped

Burnett, S. E., \& Segoria, J. (2009). Collaboration for military transition students from combat to college: It takes a community. Journal of Postsecondary Education and Disability, 22(1), 53-58. Retrieved from http://www.ahead.org/publications/jped

Cantrell, B., \& Dean, C. (2007). Once a warrior wired for life. Seattle, WA: Wordsmith Publishing.

Church, T. (2009). Returning veterans on campus with war related injuries and the long road back home. Journal of Postsecondary Education and Disability, 22(1), 10-17. Retrieved from http://www.ahead.org/publications/jped

Green, D. (2006). Historically underserved students: What we know, what we still need to know. New Directions for Community Colleges, 126, 21-28. doi: 10.1002/cc.244Herrman, D., Raybeck, D., \& Wilson, R. (2008, November 21). College is for veterans, too. The Chronicle of Higher Education. Retrieved from http://chronicle.com/

Hollins, T. (2009). Examining the impact of a comprehensive approach to student orientation. Inquiry, 14(1), 15-27. Retrieved from http://www.vccaedu.org/inquiry/

Lokken, J., Pfeffer, D., McAuley, J., \& Strong, C. (2009). A statewide approach to creating veteran-friendly campuses. New Directions for Student Services, 126, 45-54. doi: 10.1002/ss.315

Rumann, C. B., \& Hamrick, F. A. (2010). Student veterans in transition: ReEnrolling after war zone deployments. Journal of Higher Education, 81, 431458. Retrieved from https://ohiostatepress.org/index.htm?journals/jhe/ jhemain.htmVance, M., \& Miller, W. (2009). Serving wounded warriors:

Current practices in postsecondary education. Journal of Postsecondary Education and Disability, 22(1), 18-35. Retrieved from http://www.ahead.org/publications/jped

Vance, M., Miller, W., \& Grossman, P. (2010, Fall). What you need to know about 21st century college military veterans. NASPA Leadership Exchange, 11-15. Upcraft, M.L., \& Farnsworth, W. E. (1984). Orienting students to college. New Directions for Student Services, 25, 27-37. 